\title{
STUDI KOMPARASI HASIL MENDENGARKAN CERITA RAKYAT "TIMUN MAS" DENGAN MENGGUNAKAN MEDIA AUDIO DAN TIDAK MENGGUNAKAN MEDIA NONAUDIO DI SDN 033 BALIKPAPAN
}

\author{
Maryatin \\ Pendidikan Bahasa dan Sastra Indonesia \\ Universitas Balikpapan \\ Jl. Pupuk Raya, Gn. Bahagia, Balikpapan, Kalimantan Timur \\ Email: maryatin@uniba-bpn.ac.id
}

\begin{abstract}
Abstrak
Tujuan penelitian untuk mengetahui perbedaan hasil mendengarkan cerita rakyat Timun Emas dengan menggunakan media audio dan tidak menggunakan media audio pada siswakelas V SDN 033 Balikpapan. Penelitian ini dilakukan selama empat bulan mulai September, Oktober ,November ,Desember 2017. Sampel penelitian ini diambil secara acak ( random ) dengan sistem untung untungan karena jumlah populasi diatas 100 maka diambil 30\% dari populasi sebagai sampel. Hasil analisis dalam penelitian ini menunjukn bahwa hasil mendengarkan dengan media audio lebih baik, jika dibandingkan dengan hasil mendengarkan dengan tidak menggunakan media audio. Hasil perolehan adalah thitung $=4,40$ sedangkan ttabel $=2,05$ atau dinyatakan dalam bentuk presentase keberhasilan pembelajaran kelompok eksperimen sebesar $72 \%$ dab kelompok kontrol sebesar $61,33 \%$. Dengan demikian, dapat dikatakan bahwa penggunaan media audio (tipe recorder) di sekolah dasar dapat membantu dalam meningkatkan hasil mendengarkan siswa dalam memahami unsur intristik cerita rakyat yang meliputi tokoh,watak, dan latar.
\end{abstract}

Kata kunci: Mendengarkan, Studi Komparasi, Cerita Rakyat, Media Audio, Media Nonaudio

\section{Pendahuluan}

Mendengarkan adalah salah satu keterampilan berbahasa, dan sering menemukan kesulitan, sehingga tidak jarang siswa mendapat hasil yang kurang memuasakan. Hal tersebut diduga karena kurangnya fasilitas belajar yang dimiliki dalam pengajaran mendengarkan di Sekolah Dasar.

Salah satu metode untuk meningkatkan hasil belajar mendengarkan adalah penggunaan media, termasuk media audio (Tape Recorder) yang dilengkapi dengan kaset rekaman yang telah ditentukan sesuai dengan tujuan yang ingin dicapai dalam pembelajaran tersebut. Oleh karena itu, media audio dapat dijadikan salah satu media yang dapat membantu siswa Sekolah Dasar dalam menyimak/mendengarkan karena media audio dapat diprogram sesuai kebutuhan, dapat diatur tingkat volumenya, mempunyai kecepatan stabil, dan menarik atau mengasyikan. Mengingat betapa besarnya manfaat yang dapat diperoleh dari penggunaan media audio dalam pembelajaran menyimak/mendegarkan perlu adanya penelitian yang berkaitan dengan hal tersebut. Peneliti berusaha meneliti komparasi hasil menyimak dengan menggunakan media audio dan tidak 
menggunakan audio di SDN 033 Balikpapan Fasilitas yang digunakan dalam penelitian ini, meliputi tape recorder dan kaset rekaman cerita rakyat Timun Emas.

Kemajuan ilmu dan teknologi telah merambah keseluruh sendi kehidupan, demikan pula pada dunia pendidikan. Pendidikan tidak boleh ketinggalan dalam memanfaatkan teknologi yang semakin modern dalam rangka meningkatkan kualitas siswa. Hal tersebut yang menjadi alasan peneliti pemilih judul "Studi Komparasi Hasil Mendengarkan Cerita Rakyat Timun Emas dengan Menggunakan Media Audio dan Tidak Menggunaka Media Audio dan Tidak Menggunakan Media Audio pada Siswa Kelas V SDN 033 Balikpapan Tahun Ajaran 2017/2018”. Permasalahan tersebut diambil karena media audio (Tape Recorder) bukanlah suatu media yang sulit untuk didapatkan dan harganya terjangkau. Jadi, tidak ada alasan menyimak/mendengarkan tidak dapat menggunakan media audio dalam pembelajaran yang dilakukan.

\section{Metode}

Metode yang digunakan dalam penelitian ini meliputi metode penggumpulan data dan metode anailisis data. penelitian ini hanya memiliki satu variabel saja, yaitu veriabel bebas. Variabel bebas tersebut adalah perbedaan hasil mendengarkan cerita rakyat Timun Emas pada siswa kelas V SDN 033 Balikpapan tahun ajaran 2017/2018. Penelitian ini dilaksanakan selama empat bulan (September s.d Desember 2017) mulai dari observasi, validitas dan reliabilitas soal, pengumpulan data, pengolahan data hingga penyusunan akhir. penelitian ini merupakan penelitian kuantitatif eksperimen yang merupakan noneksperimen murni. Dengan demikia, penelitian ini akan menggunakan data berbentuk bilangan dengan rumusan hipotesis yang jelas untuk menguji sebuah teori dan tidak melakukan tes awal, namun dilakukan tes akhir saja. Jumlah sampel penelitian ini adalah 30 orang. Pengambilan sampel tersebut, dengan melakukan pencabutan undian pada populasi, yang sebelumnya tertulis nomor subjek penelitian 1-101 sesuai dengan jumlah populasi. Kemudian diambil secara acak 30 undian, bagi nomor undian yang terambil akan dijadikan kelompok sampel. Sesuai dengan metode yang digunakan dalam penelitian ini, yaitu noneksperimen murni yang melakukan dua perlakuan pada dua kelompok sampel, maka sampel dibagi menjadi dua kelompok yang juga ditentukan secara acak dengan cara yang sama sehingga masing-masing kelompok sampel berjumlah 15 orang. data dalam penelitian ini adalah data kuantitatif kontinu atau data berbentuk bilangan yang diperoleh dari hasil pengukuran yang berwujud penilaian terhadap hasil siswa V SDN 033 Balikpapan tahun ajaran 2017/2018 dalam menjawab soal-soal setelah mendengarkan cerita rakyat Timun Emas. sumber data penelitian ini adalah siswa kelas V SDN 033 tahun ajaran 2017/2018. pengumpulan data dalam penelitian ini dilakukan dengan menggunakan tes. Penelitian ini melakukan dua perlakuan yang berbeda dalam proses pembelajaran terhadap dua kelompok. Kelompok pertama atau kelompok eksperimen 
pembelajaran mendengarkan dengan menggunakan media audio tape recorder (kaset rekaman), sedangkan kelompok kedua atau kelompok kontrol pembelajaran mendengarkan dilakukan dengan cara dibacakan oleh guru. Pertemuan ke-10 akan dilakukan tes, yaitu menjawab pertanyaan pemahaman yang berkaitan dengan cerita rakyat yang berjudul Timun Emas, dalam bentuk soal pilihan ganda yang terdiri atas 20 soal dengan rentang nilai 10-100. Metode analisis data yang digunakan dalam penelitian ini adalah teknik analisis komprasi uji dua rata-rata dari hasil menyimak kelompok eksperimen dan kelompok kontrol dengan alfa sebesar 5\% atau 0,05.

\section{Hasil Dan Pembahasan}

Menyimak/mendengarkan merupakan istilah yang cukup populer di kalangan masyarakat karena menyimak sangat identik dengan mendengar. Russell \& Russell sebagaimana yang dikutip oleh Anderson (dalam Tarigan, 1987:28) berpendapat bahwa menyimak/mendengarkan bermakna mendengarkan dengan penuh pemahaman perhatian serta apresiasi. Pendapat yang diutarakan oleh Russel di atas, pada hakikatnya mengandung makna bahwa menyimak/mendengarkan adalah suatu kegiatan mendengar yang memerlukan konsentrasi yang tinggi agar menyimak/mendengarkan itu menjadi bermakna.

Anderson (dalam Tarigan, 1987:60) memberikan petunjuk khusus keterampilan menyima. Uraian petunjuk tersebut adalah sebagai berikut:

a. Taman Kanak-kanak (41/2-6 tahun)

1. Menyimak pada teman-teman sebaya dalam kelompok-kelompok bermain,

2. Mengembangkan waktu perhatian yang amat panjang terhadap cerita atau dongeng,

3. Dapat mengingat petunjuk-petunjuk yang sederhana.

b. Kelas Satu ( $5^{1 / 2-7}$ tahun)

1. Menyimak untuk menjelaskan atau menjernihkan pikiran atau untuk mendapatkan jawaban-jawaban bagi pertanyaan-pertanyaan,

2. Dapat mengulangi secara tepat apa-apa yang telah didengarnya,

3. Menyimak bunyi-bunyi tertentu pada kata-kata dan lingkungan.

c. Kelas Dua (6 $6^{1 / 2-8}$ tahun)

1. Menyimak dengan kemampuan memilih yang meningkat,

2. Membuat saran-saran, usul-usul, dan mengemukakan pertanyaan-pertanyaan untuk mengecek pengertiannya,

3. Sadar akan situasi, bila sebaiknya menyimak, bila pula sebaiknya tidak usah menyimak.

d. Kelas Tiga dan Empat (7²-10) tahun)

1. Sungguh-sungguh sadar akan nilai menyimak sebagai suatu sumber informasi dan sumber kesenangan, 
2. Menyimak pada laporan orang lain, pita rekaman laporan mereka sendiri, dan siaransiaran radio dengan maksud tertentu serta dapat menjawab pertanyaan-pertanyaan yang bersangkutan dengan hal itu,

3. Memperlihatkan keangkuhan dengan kata-kata atau ekspresi-ekspresi yang tidak mereka pahami maknanya.

e. Kelas Lima dan Enam (9 $1 / 2-12$ tahun)

1. Menyimak secara kritis terhadap kekeliruan-kekeliruan, kesalahan-kesalahan, propaganda-propaganda, petunjuk-petunjuk yang keliru,

2. Menyimak pada aneka ragam cerita, puisi, rima kata-kata, dan memperoleh kesenangan dalam menemui tipe-tipe baru.

Setiap aktivitas yang dilakukan tentu ada faktor yang mempengaruhi dalam aktivitas tersebut, demikian halnya dengan menyimak. Logan (dalam Tarigan, 1987:98) mengemukakan bahwa faktor yang mempengaruhi menyimak terdiri atas:

1) Faktor lingkungan, yang terdiri dari lingkungan fisik dan lingkungan sosial ;

2) Faktor Fisik ;

3) Faktor psikologis ;

4) Faktor pengalaman.

Cerita rakyat adalah cerita yang berkembang di masyarakat dan tergolong dalam cerita fiksi. Sebagian besar orang berpendapat bahwa cerita rakyat merupakan cerita yang berasal dari daerah tertentu dengan ciri khas tertentu tergantung dari mana cerita tersebut berasal. Suprapto (1993:18) mengartikan bahwa cerita rakyat adalah cerita dari zaman dahulu yang hidup di kalangan rakyat dan diwariskan secara lisan. Maksud dari penyampian tersebut, pada dasarnya menyatakan bahwa cerita rakyat adalah cerita yang sudah ada sejak lama dan berkembang dalam masyarakat secara lisan dari mulut ke mulut.

Secara umum pengertian unsur intrinsik dapat dipahami sebagai unsur yang berasal dari dalam suatu karya sastra yang merupakan unsur penyusun sebuah karya sastra tersebut. Darmawan (2003:11) berpendapat bahwa unsur intrinsik adalah unsur-unsur yang berasal dari dalam karya sastra itu sendiri, unsur yang secara faktual jalin-menjalin membentuk satu kesatuan bangunan yang disebut karya sastra.

Sumarjo (dalam Priatni, 2003 : 37) mengungkapkan bahwa unsur prosa fiksi meliputi alur, karakter atau penokohan, suasana, latar, sudut pandang, dan gaya bahasa. Pada intinya kedua pakar di atas berpendapat bahwa unsur fiksi terbagi atas enam bagian yaitu, (1) alur, (2) karakter atau penokohan, (3) suasana, (4) latar, (5) sudut pandang, (6) gaya bahasa.

Briggs (dalam Wiryawan, 1995:7.2) berpendapat bahwa media pada hakikatnya adalah peralatan fisik untuk membawakan atau menyempurnakan isi pengajaran. Lebih lanjut Wiryawan 
(1995:7.3) mendefinisikan media adalah setiap orang, bahan atau alat, atau peristiwa yang dapat menciptakan kondisi yang memungkinkan siswa untuk menerima pengetahuan, keterampilan dan sikap. Artinya, media adalah segala sesuatu yang dapat menciptakan suatu suasana belajar.

Suyatno (2003:50) berpendapat bahwa media audio merupakan media untuk menyampaikan pesan pengirim kepada penerima melalui indra pendengaran. Pada dasarnya pendapat dari para pakar tentang pengertian media audio hampir sama, yaitu media yang mengirimkan informasi yang dapat diterima dengan indra pendengaran. Dengan demikian dapat disimpulkan bahwa media audio adalah media yang dapat mengirimkan informasi melalui suara atau bunyi yang dapat diterima lewat indra pendengaran.

Suyatno (2003:50) berpendapat bahwa media audio merupakan media untuk menyampaikan pesan pengirim kepada penerima melalui indra pendengaran. Pada dasarnya pendapat dari para pakar tentang pengertian media audio hampir sama, yaitu media yang mengirimkan informasi yang dapat diterima dengan indra pendengaran. Dengan demikian dapat disimpulkan bahwa media audio adalah media yang dapat mengirimkan informasi melalui suara atau bunyi yang dapat diterima lewat indra pendengaran.

Rowtree (dalam Lengkong, 1998:21) mengemukakan bahwa media pengajaran mempunyai manfaat sebagai berikut: membangkitkan motivasi belajar siswa, anak didik dapat mengulangi apa yang telah mereka pelajari, dapat merangsang anak didik untuk belajar dengan penuh semangat, dapat diharapkan adanya umpan balik dengan segera. Jadi sangat diharapkan dalam setiap pengajaran guru semaksimal mungkin untuk menggunakan media pembelajaran.

Berdasarkan hasil yang telah dilakukan dalam penelitian ini diinterpretasikan bahwa terdapat perbedaan hasil mendengarkan cerita rakyat Timun Emas dengan menggunakan media audio (tape racorder) dan tidak menggunakan media audio (tape racorder) dalam memahami unsur intrinsik yang meliputi, tokoh. Watak, dan latar pada siswa kelas V SDN 033 Balikpapan. Hal tersebut diketahui setelah melihat hasil penelitian dengan menggunakan alat tes berupa soal pilihan ganda yang diujikan pada dua kelompok sampel, yaitu kelompok eksperimen (menggunakan tape recorder) dan kelompok kontrol (tidak menggunakan tape recorder) diakhir penelitian setelah melakukan pengajaran selama 10 pertemuan. Penghitungan yang dilakukan dengan menggunakan ttes menunjukan hasil bahwa diperoleh $t_{\text {hitung }}=4,40$ sedangkan $t_{\text {tabel }}=2,05$. Menurut pendapat Subana (2001:163) mengatakan bahwa Tolak $\mathrm{H}_{0}$ jika $\mathrm{t}_{\text {hitung }}>\mathrm{t}_{\text {tabel }}$ sehingga $\mathrm{H}_{1}$ Diterima dengan kata lain $\mathrm{H}_{1}$ : Eksperimen $>$ kontrol. Dengan demikian, dapat dikatakan bahwa penggunaan media audio (tape recorder) di sekolah dasar dapat membantu dalam meningkatkan kemampuan siswa dalam mendengarkan dan memahami unsur intrinsik cerita rakyat.

Jika, dilihat presentase perolehan nilai rata-rata kelompok eksperimen adalah $72 \%$ sedangkan kelompok kontrol sebesar $61,33 \%$. 
Penggunaan media audio yang dilakukan dalam penelitian ini menunjukkan keunggulan media audio dibanding membacakan baha diperdengarkan kepada siswa. Berdasarkan pengalaman peneliti dalam penelitian, penggunaan media audio dapat menarik minat siswa sehingga meningkatkan konsentrasi, kecepatan dan volume penyampaian bahan yang didengarkan lebih stabil. Sedangkan pada saat membacakan baha simakan kepada siswa mempunyai banyak kelemahan. Adapun kelemahan tersebut adalah sebagai berikut:

1) Seringnya siswa meminta bacaan untuk diulangi karena kurang jelas;

2) Siswa yang berada pada posisi paling belakang sering meminta agar suara guru yang membacakan diperkeras, diperlambat, dan sebagainya;

3) Kondisi guru yang tidak sehat mempengaruhi kemampuan membacakan bahan simakan yang diajarkan.

Sebagaimana diketahui bersama bahwa siswa Sekolah Dasar sangat cenderung menyukai sesuatu hal yang mereka anggap baru. Dengan demikian, dapat dikatakan bahwa hendaknya guru yang mengajar di Sekolah Dasar lebih banyak menggunakan variasi dalam mengajar salah satunya dengan menggunakan media audio tape recorder dalam melakukan pembelajaran mendengarkan cerita rakyat.

Media audio tape recorder tidak hanya dapat digunakan dalam materi cerita rakyat saja namun dapat digunakan dalam materi lain yang masih dalam lingkup mendengarkan, seperti mendengarkan pengumuman, mendengarkan peristiwa dari siaran berita, mendengarkan puisi, dan lain-lain. Media audio juga sangat mudah untuk di peroleh dengan harga terjangkau dan jika tidak memiliki cerita yang memang tersedia, kaset rekaman dapat dibuat sendiri oleh guru sesuai dengan tujuan yang ingin dicapai dalam pembelajaran yang dilakukan sebagaimana yang pernah ditegaskan oleh Broughton (Tarigan, 1987:28) bahwa pada umumnya sumber yang paling baik bagi berbagai aspek menyimak/mendengarkan adalah rekaman-rekaman yang dibuat oleh guru sendiri karena dapat disesuaikan dengan kebutuhan dan tujuan yang ingin dicapai. Dengan demikian, dapat dikatakan bahwa rekaman hasil buatan guru secara sederhanapun layak untuk digunakan asalkan sesuai dengan tujuan yang ingin dicapai dari proses pembelajaran yang dilakukan.

Menggunakan media audio tape recorder juga memberikan kemurnian pada hasil mendengarkan karena pada saat pelaksanaan tes siswa tidak memilik kesempatan untuk membuka buku, lagi pula materi yang dijadikan bahan dalam mendengarkan tidak harus terpaku buku teks pelajaran yang penting tujuan yang ingin dicapai dalam indikator dapat terlaksana. Bedasarkan hasil penelitian yang telah dilakukan dalam penelitian ini nantinya diharapkan dapat dipergunakan sebagai bahan pertimbangan bagi para guru dalam melakukan proses belajar mengajar yang berkaitan dengan materi mendengarkan agar siswa dapat termotivasi dalam mengikuti proses pembelajaran dan mendapatkan hasil yang optimal. 


\section{Simpulan}

Berdasarkan hasil analisis yang telah dikemukakan pada bab sebelumnya maka penelitian ini disimpulkan sebagai berikut:

a. Terdapat perbedaan hasil mendengarkan cerita rakyat Timun Emas dalam memahami unsur intrinsik yang meliputi tokoh, tema, dan latar pada siswa kelas V SDN 033 Balikpapan tahun ajaran 2017/2018 yang menunjukkan adanya perbedaan, yaitu $t_{\text {hitung }}=4,40$ sedangkan $t_{\text {tabel }}=$ 2,05. Jika dilihat dalam bentuk presentasi nilai rata-rata kelompok eksperimen menunjukan tingkat penguasaan sebesar 72\%, sedangkan kelompok kontrol sebesar 61,33\%.

b. Pemanfaatan media audio (tape recorder) dalam pembelajaran menyimak/mendengarkan cerita rakyat dapat meningkatkan hasil belajar.

\section{Daftar Pustaka}

Arikunto, Suharsimi. 2002. Prosedur Penelitian. Rineka Cipta: Jakarta. .2003. Dasar-dasar Evaluasi Pendidikan. Bumi Aksara: Jakarta.

Darmawan, Taufik. 2003. Apresiasi Prosa Fiksi. Departemen Pendidikan Nasional: Jakarta.

DePorter, Bobbi dkk. 1999. (Terjemahan) Ary Nilandari. 2002. Quantum Teaching. Kaifa: Bandung.

Departemen Pendidikan dan Kebudayaan. 2001. Kamus Besar Bahasa Indonesia. Balai Pustaka: Jakarta.

Lengkong, Johanna. 1998. Pemanfaatan Media Visual dalam Pembelajaran dan Hubungannya dengan Intensitas Belajar Siswa SMKN 2 Manado. Institut Keguruan dan Ilmu Pendidikan Press: Yogyakarta.

Priatni, EndahTri. 2003. Teori Sastra. Departemen Pendidikan Nasional: Jakarta.

Suherman, Erman. 1994. Evaluasi Proses dan Hasil Belajar Matematika. Departemen Pendidikan dan Kebudayaan: Jakarta.

Subana, M \& Sudrajat. 2001. Dasar-dasar Penelitian Ilmiah. CV Pustaka Setia: Bandung.

Sudjana, M.A. 2002. Media Statistika. Tarsito: Bandung.

Suprapto. 1993. Kumpulan Istilah dan Apresiasi Sastra Indonesia. Indah: Surabaya.

Suyadi. 2003. Timun Emas (Golden Cucumber). Balai Pustaka: Jakarta.

Suyatno \& Heny Subandiah. 2003. Metode Pembelajaran. Departemen Pendidikan Nasional: Jakarta.

Tarigan, Henry Guntur. 1987. Menyimak sebagai Suatu Keterampilan Berbahasa. Angkasa: Bandung. 
Usman, M. Basyiruddin. 2002. Media Pembelajaran. Delia Citra Utama: Jakarta.

Wiryawan Sri Anitah, Suwalni Sukirno, Suyatmi. 1995. Strategi Belajar Mengajar Bahasa Indonesia. Universitas Terbuka: Jakarta. 